Ana PARAUŠIĆ, Istraživač pripravnik* Institut za sociološka

i kriminološka istraživanja
Pregledni naučni rad

UDK: 351.74:342.7

Primljeno:1.4.2020.

Prihvaćeno:1.5.2020.

https://doi.org/10.47152/rkkp.58.1.2.9

\title{
INTEGRITET POLICIJE I POVREDE INTEGRITETA POLICIJE
}

\begin{abstract}
Policija predstavlja jednu odjavnih službi koja je zadužena za očuvanje javnog reda i poretka. Službenici policije mogu primenjivati silu u sprovođenju zakona, i uskraćivati neka od osnovnih prava i sloboda građanima. Iz toga razloga, integritet policije kao i njenih službenika jedno je od uvek aktuelnih teorijskih i praktičnih pitanja. Cilj ovog rada jeste da se prikažu osnovne koncepcije, debate i dileme koje se vezuju za integritet policije, kao javne organizacije. Ovo podrazumeva pre svega, prikaz glavnih određenja i objašnjenja fenomena integriteta policije, zatim prikaz najpoznatijih tipologija povreda integriteta policije, kao i nekih od faktora kojima se objašnjava postojanje povreda integriteta policije.
\end{abstract}

Ključne reči: policija, službenici policije, integritet policije, povrede integriteta policije, korupcija policije.

\section{Uvodne napomene}

Službenici policije imaju jedinstvenu ulogu u sprovođenju zakona u ime društva i predstavljaju instituciju koja ima ovlašećnje da primenjuje silu nad građanima. Policija ima značajnu moć obzirom da ni jedna druga vladina služba nema pravnu mogućnost da zadrži građane, pretraži njihove lične stvari, fizički ih 
napadne ili uskrati druga prava i slobode. Zbog ovih, i brojnih drugih razloga, ne bi trebalo da nas iznenadi to što su policijske organizacije predmet konstantnog preispitivanja šire javnosti.

Uprkos protektivnoj ulozi koja joj je namenjena, korupcija, zloupotreba autoriteta, brutalnost, kršenje ustavnih prava, ostavili su neslavan trag na rad policije u SAD (Goldstein, 1977; Sherman, 1978; Wadman, Allison, 2004; Walker, 1997), kao i u drugim zemljama (Chevigny, 1995; Punch, 1985; Stone, 2007). Poslednjih godina, federalna vlast SAD je pokrenula brojne inicijative kako bi se osnažila kultura integriteta policije kroz primenjena istraživanja (Klockars et al., 2000; Weisburd et al., 2000), treninge i selektivne aktivnosti na nivou pojedinačnih policijskih agencija. Svi ovi napori, delimično, ukazuju na zaključak da problematično i neetičko ponašanje službenika policije, odnosno povrede integriteta policije, predstavljaju jedno od kontinuirano aktuelnih pitanja u teoriji i praksi. Policija je odgovorna društvu i zajednici koje bi trebalo da štiti, te slučajevi korupcije mogu značajno da naruše povrenje građana u policiju (Desta, 2013).

Uvažavajući navedeno, autor rada zainteresovan je za način na koji se integritetu policije pristupa, pre svega, na teorijskoj ravni. Cilj rada jeste da se prikažu osnovne koncepcije, debate i dileme koje se vezuju za integritet policije, kao javne organizacije. Ovo podrazumeva pre svega, prikaz glavnih određenja i objašnjenja fenomena integriteta policije, zatim prikaz najpoznatijih tipologija povreda integriteta policije, kao i nekih od faktora kojima se objašnjava postojanje povreda integriteta policije.

\section{Određenje integriteta policije}

Može se pretpostaviti da akteri čija je primarna uloga pružanje bezbednosti, zbog prirode posla koji obavljaju i, često, ovlašćenja da primenjuju silu, moraju iskazati naročito visok nivo integriteta. Policija i njeni pripadnici, kao jedan od najznačajnijih aktera sistema bezbednosti, moraju poštovati pravila profesionalne etike i strogo se pridržavati službenih pravila. Zato je opravdano očekivati da će policijski službenici biti osobe koje odlikuju vrline poput časti i savesnosti, da će primenjivati zakon u svakoj situaciji, a njihove odluke moraju biti otvorene za preispitivanje javnosti. Na žalost, istorija policijskog rada ukazuje da ovo nije uvek slučaj i da se policajci uključuju u spektar aktivnosti koje nisu uvek u saglasju sa disciplinskim pravilima i krvičnim pravom (Newburn, 1999; Punch, 2000). Upravljanje, odgovornost, integritet policije, i povezani aspekti, su važni delovi savremenog policijskog rada za koje se veruje da zauzimaju centralno mesto u policiji kao profesiji (Pagon, Lobnikar, 2004). 
Među autorima koji su u akademskoj zajednici etablirali problematiku integriteta policije posebnu se ističu Karl Klokars i njegovi saradnici (Carl B. Klockars et al.). Nakon inicijalnog koraka koje je predstavljalo pionirsko istraživanje američke policije koje su sproveli Klokars i sardanici (1997), integritet policije bio je tema nekoliko važnih konferencija (Sixth International Conference on Ethics: Integrity at the Public-Private Interface 1998; NIJ/NYU Seminar on Police Integrity and Democracies 1999; Strengthening Police-Community Realtionship 1999; Estern Europe: Ethics, Integrity and Human Rights 2000), kao i brojnih publikacija (Principles of Promoting Police Integrity, 2001; Police Integrity and Ethics, 2004; The Contours of Police Integrity, 2004, Enhancing Police Integrity, 2006).

Istražujući problematiku integriteta policije, istraživači su tematizovali sisteme ranog upozorenja (v. Walker, Alpert, 2004; Walker, Alpert, Kennedy, 2001), monitoring i odgovornost (v. Davis et al., 2004; Hickman et al., 2004; Walker, 2001, 2005), kao i tradiocionalne oblike prekršaja policajaca (v. Garner, Maxwell, Heraux, 2004; Lerch, Mieczkowski, 2004; Smith, 2004; Terrill, Mastrofski, 2004). Ova heterogenost u istraživanju je povezana sa činjenicom da ne postoji jedinstvena definicija niti objašnjenje integriteta policije. Kako navode Hikman i saradnici (Hickman et al., 2004) čini se da istraživači određuju integritet policije najčešće na osnovu njegovog odsustva.

I pored ove poteškoće, brojni autori pokušali su da odrede integritet policije. Delatre integritet definiše kao „duboko ukorenjenu karakteristiku, rešenost i odlučnost, ustaljenu naviku ispravnog postupanja“ koje nije rezultat prisile druge osobe, već sopstvene odluke (1996: 325). Ovaj autor smatra da je integritet/ etičko ponašanje „osnova dobrog prijateljstva, braka, roditeljstva, dobrog sportiste, dobrog građanina i dobre javne službe“ (Delattre, 1996: 325, prema Pagon, 2004). U svom uvodnom obraćanju na Nacionalno simpozijumu o integritetu policije, Stiven Vićio (Stephen Vicchio, 1997) definiše osobu od integriteta kao nekog koga odlikuje koherentan i relativno stabilan set osnovnim moralnih vrednosti i vrlina, kojima je svojevoljno privržen, i koji odražava ono što kaže ili dela (Vicchio, 1997:125, prema Pagon, 2004). Taj set vrlina, kao sastavni deo integriteta pojedinačnog službenika policije, čine: opreznost/smirenost, poverenje, zanemarivanje sopstvenog interesa, hrabrost, intelektualna iskrenost, pravednost i odgvornost. Integritet policije znači da policijski službenik iskreno prihvata vrednosti i moralne standarde policijskog rada i poseduje vrline svoje profesije i dosledno i svojevoljno postupa u skladu sa tim vrednostima, standardima i vrlinama, čak i u slučaju spoljnih pritisaka (Pagon, 2000: 11).

Prema jednoj grupi autora (Michael et al., 2006), integritet službenika koji sprovode zakon odnosi se na verodostojnost ili snažno poštovanje seta vrednosti 
ili principa; skupa moralnih standarda koji omogućavaju sprovođenje zakona u modernim demokratskim društvima. U širem smislu, ovo podrazumeva sprovođenje zakona, održavanje javnog reda i pružanje usluga zajednici koje je u skladu sa ustavnim pravima i slobodama građana (Michael et al., 2006). Svaka osoba ima svoje lične moralne principe, a od pripadnika policije se zahteva naročito visok stepen integriteta koji je teško ugroziti; pripadnici policije postupaju prema visokom standardima kako u službi, tako i u svom privatnom životu. Dešon (2000) takođe ističe da službenici policije moraju da se pridržavaju moralnih i etičkih standarda koji su natprosečni.

Iako zamišljena lista vrlina može da posluži kao osnov za definisanje integriteta policijskih službenika, koncept je teško empirijski izmeriti. Naime, zanemaruje se činjenica, da integritet policije može biti odlika i organizacije, a ne samo pojedinca (Kutnjak Ivković, Khechumyan, 2014: 41). Klokarks i saradnici određuju integritet policije kao ,normativno nastojanje službenika policije da ne podlegnu iskušenjima da zloupotrebe prava i privilegije koje proizilaze iz njihovog zanimanja“" (Klockars et al., 1997, 2000, 2001, 2004). Ovaj zahtev odnosi se na različite forme iskušenja, ne samo na one koje podrazumevaju sticanje dobiti (tj. korupciju policije) već i ostala iskušenja da se zloupotrebe prava i privilegije koje proizilaze iz obavljanja policijskog posla (Klockaras et al., 2006). Isti autori (Klockars et al., 2004: 2-6) ističu da posebne profesionalne grupe koje imaju moć da donose odluke, a među njima i policija, moraju da prepoznaju problem integriteta. Oni su identifikovali šest aspekata profesionalnog integriteta koji važe za takve grupe:

- Normativnost (zajednička moralna uverenja i težnja da se ponašanje uskladi sa tim verovanjima);

- Opasnost da se podlegne iskušenju (stavovi nekada nisu prediktori ponašanja pošto se i ljudi od integriteta mogu ponašati na način za koji znaju da je pogrešan, iako zahtev za iskrenošću može da dovede do usvajanja verovanja u vrednost integriteta);

- Policija kao pojedinac ili kao grupa (određenje integriteta će se razlikovati u zavisnosti od toga da li se radi o pojedincu ili grupi);

- Iskušenja (službenici policije rade u različitim okruženjima i njihovo koruptivno/neetičko ponašanje može imati brojne i različite motive);

- Zloupotreba službenog položaja (prihvatanje poklona kao znaka dobre volje ili korišćenje pravnih mogućnosti, kao što je odluka da se ne uhapsi ili pokrene postupak protiv prijatelja);

- Prava i privilegije koje proizilaze iz zanimanja.

Organizacija koja neguje kulturu integriteta usvojila je set vrlina kao vodič o tome kako službenici policije štite i služe svojoj zajednici i njihovim žiteljima, 
što uključuje i ponašanje i držanje policijskih sližbenika i kad nisu na dužnosti. Razumevanje kulture integriteta je stoga najlakše ukoliko razmotrimo ponašanja i delovanja predodređena setom vednosti. Za službenike policije koji su usvojili kulturu integriteta veruje se da se ne uključuju u aktivnosti koje se mogu označiti kao koruptivne i nelegalne aktivnosti, kršenje prava, kršenje službenih pravila, ili ugrožavanje javnog poverenje i morala (Schefer, Martinelli, 2008: 310).

Ispitujući konture integriteta policije (contours of police integrity), Klokars i saradnici (2004) utvrdili su da postoje značajne varijacije između zemalja i kultura kada je u pitanju ovaj fenomen. Razlike u pogledu stepena integriteta policije moguće su i u okviru iste policije u jednoj zemlji, naročito kada je u pitanju decentralozovan policijski sistem, koji zapošljava veliki broj službenika, a pravni okvir delovanja policije uspostavljen je putem federalnih, državnih i sudskih propisa (Klockars, Kutnjak Ivković, 2004; Klockars et al., 2000). Integritet policije ne znači da će svi službenici policije smatrati da imaju podjednake zahteve da se ponašaju u skladu sa službenim pravilima. Stoga, čak i u istoj policijskoj agencije, konture integriteta policije u odnosu na jedan oblik prekršaja mogu se razlikovati od kontura integriteta policije vezane za drugi prekršaj (Kutnjak Ivković, 2009: 463).

Kroz dugotrajan akademski angažman na polju profesinalnog ponašanja policijskih službenika i sa njim povezan problem integriteta, Klokars i saradnici uspostavili su i teorijsku osnovu za ispitivanje integriteta policije - organizacionu teoriju integriteta policije (Klockars \& Kutnjak Ivković, 2004; Klockars et al., 1997, 2001). Zanovanu na pionirskom istraživanju Hermana Goldstajna o korupciji u policiji (Herman Goldstein, 1975, 1977), Klokaras i saradnici (2000) su organizacionu teoriju integriteta policije operacionalizovali su kroz četiri dimenzije:

1. Organizaciona pravila - Prva dimenzija postulira da su kvilitet zvaničnih pravila i način na koji su izrađenja, preneta (communicated) i shvaćena od strane službenika policije povezani sa stepenom integriteta policije (Klockars \& Kutnjak Ivković, 2004). Očekivanje je da policijske službe visokog integrieta proklamuju pravila koja eksplicitno zabranjuju koruptivna ponašanja i sprovode ih kada god dođe do prekršaja, dok su službenici dobro upoznati sa propisanim pravilima. Set pravila može varirati u zavisnosti od konkretne policijske službe, što naročito važi za ona ponašanja koja možemo označiti kao manje ozbiljne prekršaje, poput prihvatanja obroka, pića, poklona ili popusta.

2. Mehanizmi prevencije i kontrole - Druga dimenzija povezana je sa kvalitetom metoda otkrivanja, istrage i disciplinskog postupka u slučaju prekršaja u policiji (Klockars, Kutnjak Ivković, 2004: 14). Metode prevencije korupcije i kontrole variraju u opsegu od edukacije o etici, testova integriteta, proaktivnih 
istraga do reaktivnih istraga koruptivnih ponašanja i kažnjavanja korumpiranih službenika (evidencije policije, unutrašnje kontrole, pritužbe građana). Prema organizacionoj teoriji integriteta policije postoji pozitivna korelacija između postojanja i upotrebe sofisticiranog sistema prevencije korupcije i kontrole i nivoa integriteta u nekoj policijskoj službi.

3. Zakon ćutanja - Treća pretpostavka ovog teorijskog pristupa jeste da smanjenje/sužavanje zakona ćutanja (code of silence, blue code, blue curtain) (neformalna zabrana prijavljivanja nedozvoljenog ponašanja kolege) jeste ključno za razvijanje policijske službe visokog integriteta (Klockars, Kutnjak Ivković, 2004: 14). Zakon ćutanja se razvija u svakoj policijskoj službi kao posledica hijerarhizovane strukture; te je praćenje i nadzor nad pridržavanjem zakona ćutanja jedan od glavnih zadataka nadređenih. Ukoliko je zakon ćutanja široko rasprostranjen, službenici policije će biti nemi na prekršaje svojih kolega, i manje spremni da ih prijave nadređenima. Dimenzije zakona ćutanja - šta tačno podrazumeva - razlikuju se među organizacijama. Zakon ćutanja može da se odnosi samo na neznatna nepoštovanja pravila, a nekada i na najozbiljnija koruptivna ponašanja. Koga i šta tačno zakon ćutanja štiti može da varira ne samo u odnosu na različite organizacije već i u okviru jedne službe. Naročito u velikim organizacijama, kultura integriteta može da se razlikuje između policijskih stanica, okruga, radnih grupa (Klockaras et al., 2000: 2).

4. Očekivanja javnosti - Četvrta pretpostavka organizacione teorije integriteta policije odnosi se na povezanost nivoa integriteta u policiji i šireg socijalnog i političkog okruženja u kojem policijska služba deluje. Ukoliko okruženje vrednuje integritet, policijska služba će postaviti sebi šira očekivanja u pogledu integriteta (Klockars, Kutnjak Ivković, 2004).

\section{Povrede integriteta policije}

Uverili smo se da oko određenja integriteta policije i dalje ne postoji jasan konsenzus, te je nekada jako teško empirijski proveriti ovaj koncept. Jedan od načina pristupa ovom problemu, jeste operacionalizacija koncepta integriteta policije kroz prepoznavanje različitih oblika neetičkog i koruptivnog ponašanja koji predstavljaju povredu integriteta policije. Moguće je identifikovati dva osnovna nivoa u odnosu na koja se mogu proučavati ponašanja koja su označena kao povrede integriteta: individualni i organizacioni (grupni, institucionalni).

Prvobitni pokušaji da se objasni neetičko ponašanje policijskih službenika, a koje možemo označiti kao individualističko, opisuju se kao teorija „trule jabuke“ (rotten apple theory). Kada se suoče sa optužbama za korupciju, policijske 
agencije će tvrditi da je problem ograničen samo na manji broj korumpiranih službenika koji su nereprezentativni za čitavu organizaciju. Prema individualističkim tumačenjima povreda integriteta u policiji, neetička i koruptivna ponašanja viđena su kao odraz moralnog posrnuća individualnih službenika. Objašnjavanje povreda integriteta pomoću pristupa „trule jabuke“ bilo je zgodno sredstvo za službenike na višim pozicijama kako bi objasnili incidente u svojim službama (Kersten, 2000; Newburn, 1999). Ovo je pojednostavljeno objašnjenje koje omogućava organizaciji i starešinama da koruptivna ponašanja pripišu pojedincima ili njihovim manama. Borba protiv korupcije vodila se putem pažljivog odabira kandidata i agresivnog progona „moralno posrnulih“ službenika policije u pokušaju da se udalje sa pozicije pre nego što se njihovo korumpirano ponašanje proširi (Lobnikar, Meško, 2015: 343). Rešenja su bila usmerena ka potrebi kontrole neželjenog ponašanja pojedinaca. Organizacioni i kulturološki faktori, stoga nemaju značaja u interpretaciji kakva je ,trula jabuka“ (Desta, 2013).

Ovakav i slični pristupi ubrzo su ocenjeni kao jednodimenzionalni i nedovoljn obuhvatni da se izuči kompleksan fenomen povreda integriteta u policiji. Integritet policije proširio je fokus ka razvoju zdrave organizacije koja će omogućiti jačanje i održavanje snažnog karaktera i konstruktivne motivacije mnogih pojedinaca koji se pridružuju policiji (Greenberg, 1997).

Kada problem povrede integriteta posmatramo na grupnom ili organizacionom nivou tada možemo govoriti o različitim tipologijama koruptivnog ponašanja policijskih službenika koji su posledica ne samo njihovih individualnih karakteristika, već i organizacionih faktora i okruženja u kojem rade.

Među provobitnim pokušajima klasifikacije povreda integriteta policije pronalazimo onaj koji daje Leo Huberts (1998). Zasnivajući svoju tipologiju na dotadašnjim saznanjima o korupciji, zloupotrebi ovlašćenja i organizovanom kriminalu, policijskoj etici i policijskom radu autor smatra da postoje sledeći oblici narušavanja integriteta u policiji:

- Korupcija policije (zloupotreba položaja zarad sticanja lične dobiti);

- Policijska krađa i prevara;

- Sumnjiva obećanja i pokloni;

- Poslovi sa strane (,moonlighting“");

-Zloupotreba ili pristup informacijama;

- Diskriminacija i zastrašivanje (kolega, građana);

-Zloupotreba sile/moći (uključujući i korupciju iz plemenitog razloga);

- Trošenje i zloupotreba sredstava;

-Kriminalno ponašanje policajaca (van radnog vremena). 
Jednu od najćešće prihvaćenih tipologija povreda integriteta pronalazimo kod Vestmarlanda (Westmarland, 2005) koji razlikuje tri grupe ponašanja Prvu kategoriju čine administrativni i unutrašnji disciplinski prekršaji (rule bending). $\mathrm{Tu}$ autor svrstava vođenje privatnog posla, prihvatanje obroka tokom dužnosti, poklona u hrani ili alkoholu, prihvatanje slobodnih dana od starešina u zamenu za popravku kola, prihvatanje nekoliko pića u baru koji treba prijaviti. U drugoj kategoriji nalaze se takozvani prekršaji iz plemenitog razloga (noble cause) koji predstavljaju ponašanja koja nemaju očigledan finansijski motiv. Ova ponašanja direktno su povezana sa policijskom subkluturom. To su obično situacije kada službenik policije smatra da je osumnjičeni/optuženi kriv, ali usled birokratskih pravila ne može biti osuđen. Tada službenik policije uzima ,pravdu u svoje ruke“ i, u slučaju brutalnosti, Klokars (1996: 26) ističe kako neki „opasni momci“ sebe vide kao aktere kontrole kriminaliteta, a građane kao antipolicijski nastrojene, što vodi identifikovanju sa kulturnim vrednostima policije. „Deljenje pravde“ može da uključuje i popustljivost prema kolegama koji su počinili neki prekršaj. Ovo se uobičajeno označava kao, već spominjani, blue code (ili code of silence, kao blue curtain). Na kraju, treću kategoriju čine ponašanja koja podrazumevaju prisvajanje novca ili dobara. Tu spadaju prestupi poput krađe pronađenog novčanika, prihvatanje novca umesto pisanja kazne, uzimanje procetna kada se procenjuje neka šteta ili krađa predmeta iz već opljačkanje radnje.

Sličnu kategorizaciju nedozvoljenih/neetičkih/koruptivnih ponašanja daje Miler (2003: 2) ispitujući profesionalne standarde, prekršaje i uzbunjivače (whistle blowing), razlikujući tri tipa ponašanja: korupciju, druge forme policijskog kriminaliteta i disciplinske prekršaje.

Odsustvo integriteta policije se obično može identifikovati postojanjem nekog incidenta ili niza incidenata koji uključuju nelegalno, neetičko ili neprofesionalno ponašanje, ali takođe može da se odnosi i na nemogućnost da se postupi prema profesionalnim standardima službe (Garner Maxwell, Heraux, 2004). Stoga nije redak slučaj da se povrede integriteta policije često izjednačavaju sa korupcijom policije, koja se određuje kao zloupotreba ovlašćenja i autoriteta zarad sticanja lične koristi. Prema Roubaku i Barkeru (1974) korupcija policije može, u najširem smislu, da se odnosi na bilo koje ponašanje službenika policije koji prima ili očekuje da primi, usled posla koji obavlja, stvarnu ili potencijalnu materijalnu nagradu ili dobit. Dobit se može odnositi na novac, dobra ili usluge. Koruptivna ponašanja mogu uključivati ponašanja koja nisu specifična samo za policiju, poput lažnih prekovremenih sati, zloupotreba bolovanja i sl. Određenje korupcije može se proširiti tako da uključuje razmenu usluga, kako između službenika policije, tako između službenika policije i članova porodice, prijate- 
lja, uticajnih ličnosti i sl. (Desta, 2013: 241). Službenici policije mogu da kupe, trampe ili prodaju određene povlastice (radne zadatke, slobodne dane, odmore, unapređenja i sl). Takva ponašanja, od kojih većina predstavlja kršenje krivičnog prava, mogu uključivati (Desta, 2013: 241):

- Podmićivanje - službenik je svestan krivičnog prekršaja, ali neće uhapsiti počinioca u zamenu za mito;

- Zaštita - službenik policije štiti osobe uključene u kriminalne aktivnosti poput prostitucije, kockanja, konzumiranja narkotika;

- Mito - prijem robe i usluga ili novca za omogućavanje vršenja posla određenim pojedincima ili kompanijama;

- , Nameštanje slučaja“ - poništavanje istrage nakon hapšenja osmunjičenog;

- Uništavanje resursa policije;

- Širenje poverljivih informacija zarad lične dobiti;

- Krađa.

Drugi oblici ponašanja koji nisu nužno vezani za ličnu dobit, a predstavljaju povrede integriteta uključuju (Desta, 2013: 242): neiskrenost ili prikrivanje sopstvenog prekršaja ili prekršaja kolega (code of silence); diskriminacija prilkom obavljanja službenih dužnosti; prekomerna upotreba sile; falsifikovanje dokaza ili izveštaja; krivokletstvo; širenje poverljivih informacija (ali ne zarad lične koristi); pomaganje drugome u neetičkom ponašanju kroz podsticanje, saučesništvo, pomaganje, zaveru ili prikrivanje; neučtivost; neuspešna saradnja sa drugim javnim službama (Michael et al., 2006).

\section{Faktori koji utiču na povrede integriteta policije}

Opsežna akademska građa ukazuje da izvori problema vezanih za integritet policije jesu kompleskni i višeslojni. Delom se prekršaji u policiji pripisuju policijskim službama i njihovom neuspehu da regrutuju pojedince visokog integriteta, obezbede adekvatne obuke o etici, iskorene kulturu policije koja je tolerantna prema kršenju pravila, procesuiraju prekršaje, i kažnjavaju službenike koji krše pravila. Drugi eksterni faktori koji mogu uticati na prekršaje policije mogu se odnositi na pasivno tužilaštvo, popustljive sudove, nepostojanje nadzornih organa i tolerancija javnosti na prekršaje službenika policije (Kutnjak Ivković, Shelley, 2005: 438). Brojni drugi faktori koji pogoduju prekršajima u policiji variraju od pristupa „trule jabuke“ ili individualističkih tumačenja uzroka prekršaja u policiji, neprimenjivanja službenih pravila koja zabranjuju prekršaje, po- 
stavljanja niskih standarda prilikom regrutacije pa sve do nepostojanja efikasnog nadzora kao i involviranosti nadređenih u nedozvoljenim aktivnostima.

Policijski rad je zanimanje koje pruža specifične mogućnosti za devijantno ponašanje. Stajnberg i Ostern (Steinberg i Austern, 1990) sumiraju neke od razloga kojima se mogu objasniti neetički akti službenika policije. Pojedini službenici ističu kako nisu znali da je njihovo ponašanje protivno pravu ili procedurama. Neki veruju da je korupcija deo policijskog posla, i neophodna je kako bi se posao sačuvao. Neki od najdestruktivnijih primera korupcije počinili su pojedinici koji su smatrali da čine ispravnu stvar, da su postupali prema zahtevima službe, ili su se samo povinovali naređenjima. Pojedini su priznali da je koruptivno ponašanje način da se ubrza inače spor birokratizovani sistem, pomogne prijatelju, zloupotrebe ovlašćenja, zadovolji pohlepa, ostvari privatna dobit, nekome osveti, ili reši finasijski problem (Steinberg, Austern, 1990). Dejvid Karter (David Carter, 1997) navodi nekoliko različitih faktora koji mogu podstaći koruptivno ponašanje: pohlepa; individualna motivacija poput ega, seksualnog nagona, ili želje za moći; kulturna netolerancija; socijalizacija sa kolegama i/ili organizacijom; loša selekcija kandidata; neadekvatan nadozor i praćenje ponašanja; nedovoljno jasne posledice usled koruptivnog ponašanja; nepostojanje stavrne pretnje sankcije ili disciplinske odgovornosti (Carter, 1997 prema Newham, 2000).

Određen broj autora pokušao je da ustanovi set faktora koji bi mogli pomoći pri objašnjavanju integriteta policije. Šerman (Sherman, 1978) se ispitujući korupciju policije fokusirao na organizacioni, individualni i eksterni uticaj. Prema ovom autoru, službenici policije nisu imuni na "pritisak" sa kojim se suočavaju obavljajući svoje dužnosti. Autor identifikuje sledeće faktore koji mogu uticati na korupciju u policiji. To su sloboda odlučivanja, nekompetentni menadžeri, netransparentnost, preterana kolegijalnost, menadžerska tajnovitost, problemi sa statusom i povezanost sa kriminalnim svetom.

Postoje brojni faktori koji utiču na povrede integriteta policije, kako u okviru organizacije tako i u okruženju. Neki od njih su organizacione prirode, dok su drugi povezani s prirodom policijskog posla (Loree, 2009). Identifikovani su sledeći faktori:

- Kultura se uobičajeno navodi kao značajan faktor za objašnjenje korupcije i kršenje integriteta policije. Kultura obuhvata "kod tišine" i "subkulturu" koja promoviše zaštitu kolega koje krše zakon ili službena pravila.

- Organizaciona struktura i proces su vezani za subkulturu u policijskim organizacijama. Ovo znači "biti deo određenog tima", što može dovesti do pritiska da se osoba prilagodi kulturi „ekipe“, odakle i pritisak da se uključi u koruptivno ponašanje (Loree, 2009: 11). 
- Liderstvo je važan faktor kontrole povreda integriteta policije, koji može uticati direktno ili indirektno. Lideri bi trebalo da daju primer sopstvenim ponašanjem i usmeravaju zaposlene ka zajedničkom cilju - unapređenju integriteta pojedinaca i organizacija.

- Lični faktori mogu uticati na povrede integriteta i obično su posledica neadekvatne procedure odabira kandidata, regrutovanja slabo kvalifikovanih ili nekvalifikovanih osoba i ograničenja u karijeri.

- Političko okruženje utiče na rad i integritet policije jer je policija jedna od državnih institucija. Ozbiljni problemi nastaju kada je policija podređena političkim i ekonomskim elitama u datoj zemlji kako bi doprinela uvećanju njihovih prihoda (Villiam, 2002) i kada se vrši politički pritisak na osobe koje treba da napreduju (posebno do najviših pozicija u policiji), i kada pojedinačni službenici kao i čitava organizacija ne mogu da se odupru političkom uticaju (Heywood, 1997; Noor, 2009).

Istražujući institucionalne i kulturne faktore koji utiču na korupciju i kršenje integriteta policije moguće je identifikovati četiri glavna područja u kojima su moguće povrede integriteta: zapošljavanje, obuke i promocije; resursi, kao što su plate i oprema; sistemi i odgovornost unutar odeljenja; pravosuđe i zakoni i kulturološka tradicija koja onemogućava razvoj profesionalnih standarda policije (Newham, 2002). Klokars, Kutnjak Ivković i Haberfild (2005) takođe potvrđuju da su zapošljavanje, selekcija i obuka ključne komponente koje oblikuju okruženje integriteta unutar policijske službe. Pojedini autori su zaključili da meritokratski sistem zapošljavanja smanjuje nivo korupcije u nekim zemljama. Za sprovođenje sistema meritokratskog zapošljavanje neophodno je postojanje konkurentnog formalnog ispitivanja i posedovanje univerzitetske diplome (Rauch, Evan, 2000).

Jedan od najsveobuhvatnijih okvira za analizu faktora koji utiču na povrede integriteta policije predstavio je Klitgar (Klitgaard,1991: 94-95). Faktori koje on identifikuje su: selekcija poštenih osoba; povećanje plata i nagrada za poštene aktivnosti; kažnjavanje korumpiranog ponašanja; okruženje koje podstiče otkrivanje devijantnog ponašanja i podrška za uzbunjivače; smanjenje diskrecionih ovlašćenja; rotacija osoblja; kontinuirane obuke i promena organizacione kulture. Ispitujući povezanost uticajnih faktora i povreda integriteta u saobraćajnoj policiji Pakistana, Kalid (2016) usvaja sličnu tipologiju. Međutim, autor napominje da u istraživanje nije moguće uključiti sve faktore, već uglavnom one koji su karaktersitični ili se najčešće mogu identifikovati na organizacionom nivou (Khalid, 2016: 5). Faktori koje on ispituje su: plata i sistem nagrađivanja, regru- 
tacija i selekcija, nadzor i kontrola, organizaciona kultura, kvalitet obuke, socio-ekonomski i politički uslovi i liderstvo.

Marše (2009) je na osnovu sekundarne analize rezultata ispitivanja integriteta američke policije razvio ekonometrijski model kojim se mogu objasniti koruptivna ponašanja policijskih službenika. Tom prilikom je indentifikovao set faktora koji mogu uticati na nivo integriteta policije. Ti faktori su: selekcija službenika, treninzi i edukacija, liderstvo, ponašanje nadređenih (command behaviour), supervizija, kultura policije, organizaciona struktura, disciplinska struktura, vrednosti zajednice i politički i ekonomski uslovi. Autor ističe da bi objašnjavanje korupcije i integriteta policije pomoću svih ovih faktora bilo idealno, ali da je, imajući u vidu ograničenost dostupnih podataka, moguće razviti eksplanatorne varijable koje se odnose na liderstvo ${ }^{1}$, organizacionu strukturu ${ }^{2}$ i kulturu policije ${ }^{3}$ (Marche, 2009: 471-73).

Neki od elemenata kulture policije ili subkulture jesu među faktorima koji se najčešće povezuju sa povredama integriteta policije. Tako Stodard (Stoddard, 1983) ističe kako socijalizacija u organizaciji može imati veliku ulogu kada novi regrut prihvata da učestvuje u nedozvoljenim aktivnostima jer mu u suprotom preti neformalno odbacivanje od strane kolega. Jasno je da, ukoliko novozaposleni preduzme neku aktivnost koja je povreda integriteta, norme koje usvaja od svojih kolega imaće prednost u odnosu na formalna pravila službe. Skolnik (Skolnick, 2002) opisuje zakon ćutanja (blue code of silence) kao nepisano normativno pravilo koje je sastavni deo kulture policije. On ne podrazumeva samo tajnost, več i snažnu odanost kulturi policije koja je identifikovana kao podstičući element koruptivnog ponašanja, dok istovremeno otežava bilo kakve istražne aktivnosti (Newburn 1999). Panč (Punch, 2000) ističe da se uz podršku nadređenih, službenik policije uključuje u devijantno ponašanje čime mu se pruža opravdanje i racionalizacija postupka. Krank (Crank, 1998) takođe smatra da je kultura policije faktor koji utiče na korupciju i devijantno ponašanje. Prema njegovim rečima, ova kultura podstiče solidarnost, konspirativnost i cinizam među policajcima.

1 Indikator liderstva sastoji se od dve varijable: da li je ispitanik na nekoj supervizorskoj poziciji i da li ispitanik smatra da je opisano ponašanje narušavanje službenih pravila.

2 Uzimajući u obzir broj službenika policije i tip policijske službe, indikator organizacione strukture odnosi se na to da li je služba odeljenje načelnika, veoma velika služba ili veoma mala služba.

3 Kultura policije odnosi se na kulturu zanimanja koju novozaposleni moraju da nauče. Priroda policijskog posla i hijerarhijska struktura policije zahtevaju da službenici uče tokom procesa socijalizacije, te da će ignorisanje prekršaja kolege omogućiti novozaposlenom da stekne poverenje i podršku svojih kolega. Kultura policije podrazumeva postojanje zakona ćutanja a svaki službenik policije mora da nauči šta sve podrazumeva zakon ćutanja u konkretnoj organizaciji. Specifičan zakon ćutanja doprineće i različitim nivoima integriteta u različitim organizacijama. Kultura policije pod uticajem je selekcije, treninga i edukacije. Ovi faktori uticaće na to u kojoj meri će novi regrut u konkretnoj policijskoj organizaciji prisvojiti obrasce policijske kulture. 
Mora se istaći da ne postoji samo jedan faktor ili jednostavno objašnjenje povreda integriteta policije i postoji snažna veza između brojnih eksplanatornih faktora. Neetičko ponašanje koje predstavlja povredu integriteta može biti proizvod kombinacije nekoliko seta faktora: individualnih, organizacionih i kulturoloških (Schafer, Martinelli, 2008). Takođe, povrede integriteta policije imaju brojne uzroke i manfistacije koje rezultuju ugrožavanjem rada policije, učvršćuju zakon ćutanja, smanjuju odgovornost službenika policije i podrivaju legitimitet policije (Kutnjak Ivković, 2005).

\section{Zaključne napomene}

Imajući u vidu značaj koji se pripisuje integritetu kao odlici pojedinaca (policijskog službenika), ali i organizacije (policije), ne iznenađuje da je značajan akademski napor usmeren ka prepoznavanju načina na koji se integritet može ugroziti, kao i preporučenim startegijama za njegovu izgradnju, zaštitu i unpređenje. Uobičajeno se pretpostavlja da osobe koje obavljaju javno značajne poslove odlikuje visok stepen integriteta. Međutim, za javne organizacije i institucije naročitu bezbednosnu pretnju predstavljaju slučajevi kada se službena lica angažuju u niz aktivnosti kojima se krše propisana pravila ponašanja.

Ovde ćemo samo napomenuti, neke od izazova akademskog istraživanja integriteta policije i njegovog ugrožavanja, iako ovo pitanje zahteva zaseban rad. Istraživanje u oblasti integriteta policije je izazovno zbog povezanosti sa devijantnim ponašanjem čiji počinioci ne žele da budu otkriveni i o čijim postupicma nije poželjno javno diskutovati. Istraživač se nalazi pred problemima pristupa ispitanicima, koa i pouzdanosti i validnosti podataka. Tamna brojka devijacije policije je velika nepoznanica jer pojedini službenici ostaju nezainteresovani za različite prestupe svojih kolega ili ih ignorišu jer su i sami uključeni u nedozvoljene aktivnosti (Newburn, 1999; Sherman, 1974). Za istraživače problem može predstvaljati i postojanje norme zaštite svojih kolega - takozvani zid ćutanja (ili plava zavesa ili zakon ćutanja) - kao i tendencija da se zaštiti profesija i organizacija imajući u vidu da je policija često predmet kritike i može se ponašati kao ugroženo ,pleme“ (Crank, 1998; Skolnick, 2000). Problem otkrivanja korupcije proizilazi i iz korist koje svi akteri ove nedozvoljene aktivnosti mogu imati, kao i usled toga što ne postoji direktna žrtva koja bi prijavila ovo krivično delo (Klockars et al., 2000).

Pošto osobe anagažovane u koruptivnim aktivnostima teško mogu biti subjekti posmatranja, izazov je proceniti obim ili razmere povreda integriteta direktno, kvantitativno i empirijski. Istraživači su primenili različite tehnike kako bi prevazišli ovaj problem. Pojedini analiziraju zvanične podatke (Fyfe, Kane, 
2001), ali obzirom da slučajevi korupcije obično ostanu neprijavljeni, zvanična statistika (broj službenika policije koji su kažnjeni ili otpušteni) u najboljem slučaju može se posmatrati kao mera antikorupcijskih napora, pre nego nivoa korupcije. Drugi pristup podrazumeva opisivanje koruptivnih ponašanja od strane službenika policije, što je takođe problematično, pa ni uverenja o poverljivosti ne mogu biti dovoljna garancija za policijske službenike da će njihov identitet ostati neotkriven (Johnson, 2003: 20). Ovo su samo neke od prepreka koje stoje pred istraživačim integriteta policije, koji iako nalažu oprez i dodatni napor, ne bi trebalo da deluju destimulišuće na akademsku praksu.

Postojeća istraživanja o integritetu policije kao i povredama policijskog integriteta predstavljaju značajno istraživačko polje. Razumevanje različitih formi prekršaja, može olakšati prepoznavanje njihovih različitih posledica i efekata, te $u$ tom smislu izučavanje tipologija povrede integriteta policije ima i praktičnu vrednost. Možemo očekivati da će postojati razlike u načinu na koji organizacije ili vlade razvijaju specifčne politike i aktivnosti u odnosu na različite forme povreda integriteta. Razlikovanje tipova integriteta olakšava identifikovanje sličnosti i razlika između njihovih uzroka i posledica, što u krajnje može dovesti do formulacije efikasnijih praksi unapređenja integriteta.

\section{Literatura}

- Carter, S. (1997) Integrity. New York: Harper Perennial

- Chevigny, P. (1995) Edge of the knife: Police violence in America. New York: New Press.

- Crank. J.P. (1998) Understanding Police Culture. Lexington, KY: Anderson Publishing Co.

- Davis, R. C., Ortiz, C. W., Henderson, N. J., \& Miller, J. (2004) Turning necessity into virtue: Pittsburgh's experience with a federal consent decree. In A. R. Piquero, J. R. Greene, \& M. J. Hickman (Eds.) Police integrity and ethics. Belmont, CA: Wadsworth, pp. 3-20.

- Delattre, E. J. (1996) Character and Cops: Ethics in Policing (3rd edition). Washington, D.C.: The AEI Press.

- Deshon, R. (2000) Police Officers' Oath of Office and Code of Ethics: A Question of Knowledge (Master's thesis). Ypsilanti, MI: Eastern Michigan School of Police Staff and Command.

- Desta, Y. (2013) Applying a US police integrity measurement tool to the Eritrean context: Perceptions of top-level Eritrean police officers regarding police 
misconduct. Journal of Organisational Transformation \& Social Change, 10(3), 238-261.

- Fyfe, J. \& Kane, R. (2001) Changes in Patterns of Career-Ending Misconduct. In: Annual meeting of the American Society of Criminology, 7 November 2001. Atlanta: American Society of Criminology.

- Garner, J. H., Maxwell, C. D., \& C. Heraux (2004) Patterns of Police Use of Force as a Measure of Police Integrity. In: M. Hickman, A. R. Piquero \& J. R. Greene (Eds.) Police Integrity and Ethics. Belmont, CA: Wadsworth/Thomson Learning, pp. 109-125.

- Goldstine, H. (1975) Police Corruption: Perspectives on its nature and Control. Washigton, D.C.: Police Foundation.

- Goldstine, H. (1977) Policing a Free Society. Cambridge, MA: Ballinger.

- Greenberg, S. F. (1997) Executive summary. In: S. J. Gaffigan, \& P. P. McDonald (Eds.) Police integrity: Public service with honor. Washington, DC: U.S. Department of Justice, pp. 1-6.

- Heywood, P. (1997). Political corruption: Problems and perspectives. Political Studies, 45(3), 417-435.

- Hickman, M., Piquero, A. R., \& J. R. Greene (Eds.) (2004) Police Integrity and Ethics. Belmont, CA: Wadsworth/Thomson Learning

- Huberts, L. W. (1998) What can be done against public corruption and fraud: expert views on strategies to protect public integrity. Crime, Law and Social Change, 29(2-3), 209-224.

- Johnson, D. T. (2003) Above the law? Police integrity in Japan. Social Science Japan Journal, 6(1), 19-37

- Kersten, J. (2000) Police Powers and Accountability in a Democratic Society: Introductory Report. European Journal on Criminal Policy and Research, 8(3), 237-245.

- Khalid, S.U. (2016) Theory and practice of police corruption in Pakistan (Doctoral thesis). Amsterdam: Vrije University

- Klitgaard, R. (1991) Controlling Corruption. Berkeley, CA: University of California Press.

- Klockars, C.B. (1996) A theory of excessive force and its control. In: W.A. Geller $\&$ H. Toch (Eds.) Police violence: Understanding and controlling police abuse of force. New Haven: Yale University Press, pp. 1-22.

- Klockarks, C.B., Kutnja, S., Harver, W. \& Haberfeld, M.R. (1997) The measurement of police integrity. Washington, D.C.: U.S. Department of Justice, Office of Justice Programs, National Institute of Justice. 
- Klockar, C.B., Kutnaj Ivković, S., Harver, W.E. \& Haberfeld, M.R. (2000) The measurement of police integrity. Washington, D.C: Nationa institute of justice, research in Brief.

- Klockars, C. B., Kutnjak Ivković, S., Haberfeld, M. R., \& Uydess, A. (2001) Enhancing police integrity: Three case studies. Washington, D.C.: US Department of Justice, Office of Justice Programs, National Institute of Justice.

- Klockars, C. B., Ivkovic, S. K., \& Haberfeld, M. R. (2004). The contours of police integrity. Thousand Oaks, CA: Sage Publications.

- Klockars, C. B., Kutnjak Ivković, S., \& Haberfeld, M. R. (2006) Enhancing police integrity. New York, NY: Springer.

- Klockars, C. B., Kutnjak Ivković, S., \& Haberfeld, M. R. (2005). Enhancing police integrity. Washington, DC: National Institute of Justice, Research for Practice.

- Klockars, C. \& Kutnjak Ivković. S. (2004) Measuring police integrity. In: A.R. Piquero, J.R. Greene \& M.J. Hickman (Eds.) Police Integrity and Ethics. Belmont, CA: Wadsworth Publishing, pp. 3-20.

- Kutnjak Ivkovic, S. (2009) The Croatian police, police integrity, and transition toward democratic policing. Policing: An International Journal of Police Strategies \& Management, 32(3), 459-488.

- Kutnjak Ivković, S., \& Khechumyan, A. (2014) Measuring police integrity among urban and rural police in Armenia: From local results to global implications. International Journal of Comparative and Applied Criminal Justice, 38(1), 39-61.

- Kutnjak Ivkovic, S., \& Shelley, T. O. C. (2007) Police integrity and the Czech police officers. International Journal of Comparative and Applied Criminal Justice, 31(1), 21-49

- Kutnjak Ivković, S. (2005) Fallen blue knights. New York, NY: Oxford University Press.

- Lersch, K. M. \& T. Mieczkowski (2004). Armed and Dangerous: Exploring Police Drug Use and Drug Related Corruption. In: M.Hickman, A. R.Piquero \& J. R. Greene (Eds.) Police Integrity and Ethics. Belmont, CA: Wadsworth/Thomson Learning.;

- Lobnikar, B., Meško, G. (2015) Perception of police corruption and the level of integrity among Slovenian police officers. Police Practice and Research, 16(4), 341-353.

- Loree, D. (2009) Corruption in Policing: Causes and Consequences A Review of the Literature. Ottawa: Royal Canadian Mounted Police (RCMP).

- Marché, G. E. (2009) Integrity, culture, and scale: an empirical test of the big bad police agency. Crime, law and social change, 51(5), 463-486. 
- Michael, R., Scharf, P., \& Unter, H. (2006) Managing Law Enforcement Integrity: The State of Art. New Orleans: Center for Society Law \& Justice.

- Miller, J. (2003) Police Corruption in England and Wales: An assessment of current evidence. London: Home Office.

- Newburn, T. (1999) Understanding and preventing police corruption: Lessons from the literature (Police Research Series. Paper 110). London: Home office policing and reducing crime unit.

- Newham, G. (2000) Towards Understanding and Combating Police Corruption. Crime \& Conflict, 9, 21-25.

- Newham, G. (2002) Promoting Police Integrity at Station Level: The Case of the Hillbrow Police Station. Urban Forum, 13(3), 20-52.

- Noor, M.T. (2009) Institutional Dynamics of Governance and Corruption in Developing World: The Case of Pakistan. (PhD Thesis). Heidelberg: Faculty of Economics and Social Studies, Ruprecht-Karls-Universitat.

- Pagon, M. (2000) Police ethics and integrity. In: M. Pagon, (Ed.) Policing in Central and Eastern Europe: Ethics, Integrity and Human Rights. Ljubljanja, Slovnia: College of Police and Security Studies, pp. 3-14.

- Pagon, M. (2004) A study of police reform in Slovenia. In: M. Caparini \& O. Marenin (Eds.) Transforming Police in Central and Eastern Europe. Muenster: Lit Verlag, pp. 115-30.

- Pagon, M. \& Lobnikar, B. (2004) Police integrity in Slovenia. In: C.B. Klocakrs, S Kutnjak Ivković \& M.R. Haberfeld (Eds.) The contours of police integrity. Thousand Oaks, CA.: Sage, pp. 212-231

- Punch, M. (1985) Conduct unbecoming. London: Tavistock Publications.

- Punch, M. (2000) Police corruption and its prevention. European Journal on Criminal Policy and Research, 8, 301-324.

- Raines, J. (2006) Ethics, Integrity, and Police Misconduct: Analyzing Ethical Awareness, Standards and Actions of Law Enforcement Offices in the United States. (PhD thesis). Raleigh: North Carolina State University.

- Rauch, J.E., \& Evans, P.B. (2000) Bureaucratic structure and bureaucratic performance in less developed countries. Journal of Public Economics, 75(1), 49-71.

- Schafer, J. A., \& Martinelli, T. J. (2008) First line supervisor's perceptions of police integrity: The measurement of police integrity revisited. Policing: An International Journal of Police Strategies \& Management, 31(3), 306-323.

- Sherman, L. (1974) Police corruption: A sociological perspective. Harlow: Anchor Press.

- Sherman. L.W. (1978) Scandal and Reform: Controlling Police Corruption. Berkeley: University of California press. 
- Skolnick, J.H. (2000) Code blue: Prosecuting police brutality requires penetrating the blue wall of silence. The American Prospect, 49-53.

- Skolnick, J. (2002) Corruption and the blue code of silence. Police Practice and Research, 3(1), 7-19.

- Smith, S. (2004) Citizen behavior and police use of force: An examination of national survey data. In: A. R. Piquero, J. R. Greene, \& M. J. Hickman (Eds.) Police integrity and ethics. Belmont, CA: Wadsworth, pp. 127-138.

- Steinberg, S. \& Austern, D. (1990) Government, Ethics, and Managers: Solving Ethical Dilemmas in the Public Sector. Westport, CT: Praeger.

- Stoddard, E.R. (1983) Blue Coat Crime. In: C.B.Klockars, (ed.) Thinking About the Police. New York: McGraw-Hill.

- Stone, D. (2007) Tracing police accountability in theory and practice: from Philadelphia to Abuja and Sao Paulo. Theoretical Criminology, 11, 245-59.

- Terrill, W. \& S. D. Mastrofski (2004) Toward a Better Understanding of Police Use of Nonlethal Force. In: M. Hickman, A. R. Piquero \& J. R. Greene (Eds.) Police Integrity and Ethics. Belmont, CA: Wadsworth/Thomson Learning, pp. 141-161.

- Wadman, R.C. \& Allison, W.T. (2004) To Protect and to Serve: A History of Police in America. Upper Saddle River, NJ: Pearson Prentice-Hall.

- Walker, S., \& Alpert, G. (2004). Early intervention systems. In A. R. Piquero, J. R. Greene, \& M. J. Hickman (Eds.) Police integrity and ethics. Belmont, CA: Wadsworth, pp. 21-35

- Walker, S. (2005) The new world of police accountability. Newbury Park, CA: Sage.

- Walker, S. (1997) A Critical History of Police Reform, Lexington, MA: D.C. Heath.

- Walker, S. (2001) Police accountability: The role of citizen oversight. Belmont, CA: Wadsworth.

- Walker, S., Alpert, G., \& Kennedy, D. (2001) Early warning systems: Responding to the problem police officer. Washington, DC: National Institute of Justice.

- Weisburd, D., Greenspan, R., Hamilton, E.E., Williams, H. \& Bryant, K.A. (2000) Police Attitudes Toward Abuse of Authority: Findings from a National Study. Washington, D.C.: National Institute of Justice.

- Westmarland, L. (2005) Police ethics and integrity: Breaking the blue code of silence. Policing and Society, 15(2), 145-165. 
Ana PARAUŠIĆ

Institute of Criminological and Sociological Research

Research assistant

\section{POLCE INTEGRITY AND VIOLATIONS OF POLICE INTEGRITY}

The police represents one of the public services in charge of maintaining law and public order. Police officers can use force and deny and restrict some of the fundamental rights and freedoms to citizens. For this reason, the integrity of the police as well as its officers is one of the most importatnt theoretical and practical issues in police work. The aim of this paper is to present the basic concepts, debates and dilemmas related to integrity of the police as a public organization. This entails, first of all, an outline of the main definitions and explanations of the phenomenon of police integrity, then an overview of the most notable typologies of violations of police integrity, as well as some of the factors that explain the existence of violations of police integrity.

Key words: police, police officers, police integrity, violations of police integrity, police corruption 